International Research Journal of Management, IT \& Social Sciences
Available online at https://sloap.org/journals/index.php/irjmis/
Vol. 7 No. 2, March 2020, pages: 50-58
ISSN: 2395-7492
https://doi.org/10.21744/irjmis.v7n2.879

\title{
School Motivation Through the use of Information and Communication Technologies (ICT)
}

José Gregorio Lucas Delgado ${ }^{\text {a }}$ José Alberto Vigueras Moreno ${ }^{b}$

Article history:

Submitted: 27 January 2020

Revised: 09 February 2020

Accepted: 18 March 2020

\section{Keywords:}

abilities;

meaningful learning;

school motivation;

skills;

technological tools;

\begin{abstract}
School motivation is a process that includes aspects of cognitive and affective type, related to the teaching-learning process, which involves the school trilogy (educators, students and parents) who participate dynamically and actively in academic development. This research was intended to demonstrate that teachers can motivate students in the teaching-learning process under the potential of Information and Communication Technologies to achieve the activation of cognitive resources, since currently, it can be counted with different applications that are very useful at the time of teaching, making use of innovation, leaving aside the traditionalism where the teacher was the protagonist and giving that role to the student, digital native. Finally, it is evident how the student, being motivated by his teacher, manages to pass the different barriers that may arise in the realization of the educational activities, being necessary that the educator is constantly motivating and giving merits to the students, even if he does not comply the established parameters, offering them new strategies so that they can fulfill the proposed activities.
\end{abstract}

International research journal of management, IT and social sciences (C) 2020. This is an open access article under the CC BY-NC-ND license (https://creativecommons.org/licenses/by-nc-nd/4.0/).

\section{Corresponding author:}

José Gregorio Lucas Delgado,

Pontificia Universidad Católica del Ecuador Manabí, Portoviejo, Ecuador.

Email address: jlucas8463@ pucem.edu.ec

a Pontificia Universidad Católica del Ecuador Manabí, Portoviejo, Ecuador

Pontificia Universidad Católica del Ecuador Manabí, Portoviejo, Ecuador 


\section{Introduction}

Motivation is a process that encourages the individual to conduct and sustain it for their interest (internal factors) or a benefit (external factors). In the educational field, motivation plays a preponderant role, since it directly influences the teaching-learning process, since it predisposes the student to acquire new knowledge, develop skills and abilities through experience, observation and instruction that lead him to significant learning, in addition to allowing you to maintain a lasting or permanent positive behavior, taking into account personal, biological, social, economic, environmental and technological factors, currently one of the difficulties that exist is not taking advantage of ICT, to achieve motivation in the teaching-learning process (Herianto, 2017).

Information and Communication Technologies are part of this motivational school process, they are actively and dynamically present in every teaching-learning process, which contributes a large percentage in the proposed school activities generating a relevant, positive impact on the population student. The motivation for good school performance is a problem that deserves the attention of students, teachers, parents, and authorities in general terms, sometimes it is called school predisposition or aptitude, other times, good performance; Whatever terminology or semantic meaning is given, it is nothing more than the assimilation of learning, expressed in a meaningful way at the highest level and which is reflected in the mood of the students as a result of a process of instruction or training academic. It brings with it the good academic performance with the firm purpose of reaching a goal or objective, said academic achievement varies according to the circumstances since it involves intellectual factors, personality, aptitudes and personal interests, study habits, economic conditions, self-esteem and the interaction between the teacher and the student.

According to Sandoval et al. (2018), point out that it is worthwhile to know the factors that positively affect the process of teaching children, girls and adolescents to protect them from problems such as: dropping out, school failure, low self-esteem and therefore low academic performance, taking into account that this process is directly related to the sociocultural, family, community, school part Curriculum. Education is aimed at the formation of innovative knowledge, where the motivation and use of current technological tools are of vital importance to make this activity become a culture and not just a fashion, to reconcile the change for change and reject the past far removed from criticality and reflection. That is why, it is based on meaningful learning, linked to the transformative action of the world. It has a deep sense of change because it generates typologies that are not given by direct generation. They must be determined and projected so that the learning process reaches the desired skills and abilities, applied to the different fields of society. As indicated (Vega, 2016), the incorporation of ICTs into education has been a positive transformation, considering the responsibility that all education actors have over this pedagogical reality; This technological initiation has been taking place throughout history and draws a constant and very angry controversy among those who are in favor or against the moderation with which it should be used. From this point of view, it can be considered as a vertiginous social change that implies the dynamism, reception, and adaptation of the so-called educational technology.

But, although it seems contradictory, the effort and technical ability and skills are not a guarantee of school motivation at its best, these perceptions, although they sound complementary, interesting and dynamic, do not have the same value for students as long as there is no predisposition and a good burden of responsibility as a relevant factor of good academic performance. Knowing these difficulties, the objective of the research is to demonstrate the influence that school motivation exerts under the potential of Information and Communication Technologies, in addition to the different internal and external factors that directly and indirectly influence the acquisition of knowledge of students in the classroom, in addition to knowing the roles of those involved in the teaching-learning process, as well as the influence of technology in the educational process, and how the teacher can make use of it to achieve better assimilation of the planned contents. Therefore, it is intended in this paper to argue the hypothesis that, if teachers manage to motivate students under the potential of the use of ICT, students with better results in the teaching process, with adequate academic preparation and a better exchange between teacher-student (Estevez et al., 2018).

\section{Materials and Methods}

This article is supported by the research analysis, complying with the requirements for the collection of qualitative and hermeneutical information. From the description, and the initial inductive-deductive approach was used based on logical reasoning strategies that allowed us to reach the precise conclusions of the problem raised. Considering the experiential contributions of school motivation, educational innovation and the use of ICT, its importance and most relevant characteristics, the positive and negative factors that are immersed in educational agents.

Delgado, J. G. L., \& Moreno, J. A. V. (2020). School motivation through the use of information and communication technologies (ICT). International Research Journal of Management, IT and Social Sciences, 7(2), 50-58.

https://doi.org/10.21744/irjmis.v7n2.879 
Contextualization refers to the breaking of paradigms or harms when opening up to new events and learning scenarios through ICT to form leaders regarding quality education in children and adolescents. Currently, technology provides the training of better observers engaged in the improvement of teaching and learning habits, thus achieving a faster, effective, efficient and interactive way in the process of innovative education.

\section{Results and Discussions}

\section{Definition of school learning}

School learning is the appropriation of knowledge, skills, and values acquired in the cognitive development of students; it is the repetition of an established process that involves time, space, resources, and skills that allow them to cope and survive (Pérez \& Gardey, 2012). They point out that there are many versions of how human beings learn, such as Pávlov, who argues that knowledge is obtained through synchronous stimuli or the contribution of Piaget who focuses on cognitive development from the analysis.

At the discretion of García \& Doménech (2014), the child learns at every stage of his life, from his first educational steps to the last of his life, he acquires different types of learning in the classroom, the same ones that little by little They are put into practice at the necessary time, currently teachers apply different types of strategies to better reach the student, thus achieving that the teaching-learning process is not disrupted. Currently, ICTs play a very important role in the learning process of students, they make the different types of content more dynamic, which they wish to broadcast so that the process has greater assimilation on the part of students, who have a wide variety of free or paid applications, and that can be applied to different areas of education (Rick \& Weber, 2010; Huang et al., 2011; Chai, 2011; Huang \& Chiu, 2015). It should be noted that the learning process presents different types of difficulties that directly affect the students, among which cognitive problems are mentioned as one of the main obstacles, for which the teacher must be prepared, to largely bypass this flaw, motivating day by day in search of assimilation of content they present in this process, ICTs play a very important role in the educational part, providing more than one option for teachers to be able to comply with the assimilation of the contents.

\section{Definition of motivation}

The term motivation comes from combined Latin words: Latin Motus (moved) and motio (movement) and from Psychology and Philosophy, is what drives an individual to perform actions and sustain their actions and conduct until you can reach your goal; It is the will and interest that comes to reach stated goals, implies an absolute, relative or pleasant need for what is considered essential and adequate. The human being by nature can acquire and assimilate what happens around him, although these actions are not always given at the right and appropriate time. The incorporation of motivational learning stimuli has significant positive and negative long-term impacts as indicated (Lasala et al., 2013).

In the meantime, motivation should be defined as the engine that directly influences the behavior of every individual and that leads them to be part of positive or negative changes both in the school and in the personal sphere, therefore, the motivation does not It is a unitary process, but includes diverse constructive elements, perfectly concatenated that directly influence the formation and actions of the same. The motivation is based on the effort to reach a goal, adjusted to the need for school, personal or work satisfaction, governed by a theoretical framework of how it is produced and how it will influence the actions of individuals, how to improve the teaching practice and the psycho-pedagogical approach granted.

It is necessary to recognize that motivation begins from the prenatal stage, with parents, constituting the family as the environment where stimulation begins and that ensures interest or enthusiasm for studies or work; the development of an activity, the pursuit of satisfaction, require external agents inherent in its actions, as well as multidimensional constructs. Every individual who engages in an activity with pretensions of personal stimulating and positive sensations activates the intrinsic motivation related to the desire to know and learn new concepts, to overcome or complete the goals set personally, while in the extrinsic motivation according to Usán \& Salavera (2018), three types are distinguished: the external one, which refers to the rewards or to avoid punishments; the one identified, which includes the personal value in actions considered important and introjected, where the action is aimed at avoiding guilt or extolling your ego. Motivation is always a necessity, but not abstract, but concrete conceptualized as a personality trait, mood or temporary situation that follows common patterns and responds to the personality of each individual. 
Protagonists of the motivation:

Role of the teacher

Teachers have an important role in the teaching-learning process of students, so they need to know their degrees of motivation, in any of the disciplines or subjects taught. He must impart his knowledge with a high dose of affectivity, creativity, without neglecting the promulgation of the values that must be deeply rooted in each one of them to turn them into full citizens.

The effective motivation will depend on the teacher, who must associate the interest of the students with the awareness and decisions, linked to the need to learn and develop their autonomy, becoming a valuable element for their family and society with aspirations and crystallized goals both professionally and humanly. Motivation is a complicated construct that concerns various reasons. On the one hand, it refers to daily life and the actions that are taken, on the other hand, it links the scientific part, regardless of whether the action is common or specific. Substantial is how motivation is professed, beyond the usefulness, precision or specific operation. (Precht et al., 2016).

The teacher must capture the attention of the students, responsibly enliven the individual or group activities proposed in a compensatory and subsidiary manner. To motivate is to generate the necessary conditions to teach the class; in this sense, a motivating teacher is histrionic, charismatic and talkative, knowledgeable about student interests; it must promote school learning and encourage the desire to learn.

For Horch (2016), the teacher must be able to develop a series of fundamental competencies such as planning, organizing their work, communicating, working cooperatively, establishing satisfactory interpersonal relationships and resolving conflicts, as well as having a positive and sincere self-concept, apply constant professional self-evaluation, use appropriate educational technologies, but above all be a source of motivation for their students and classmates. He must become the designer of new challenges and dreams, an engineer of paths not yet traveled, whose walk implies wills with an often uncertain beginning and a satisfactory end; He must promote learning experiences with a specific context to the interests of the students, but for this, he must know where his disciples are in the learning process, in addition to being able to encourage them to advance and reach new stages of knowledge.

It is the teacher who passionate about the student, so that he becomes a designer of his ideas and learning experiences, generating his ideas. Since the objective of education is that students are fully motivated to acquire global skills that allow them to improve the world, the role of the teacher is to be an entrepreneur (teacher-preneur), a social innovator who knows how to convey to his student's enthusiasm and the commitment to do good for their benefit and that of others. For Ospina (2015), the motivation indicates that it becomes the main motor of learning, this can be like a spark for the student, it sets goals and objectives, the same that turn into accomplished achievements, the motivation must Be consistent in the classroom, as it is shown that if the teacher does not motivate their students they feel they are in a very monotonous and traditional class.

\section{Role of educating}

Motivation is closely related to the student and their willingness and interest to take advantage of the knowledge imparted, developing their abilities, capturing their attention and overcoming their limitations. Being necessary to place it in the center of learning and recognize it as protagonists of it, which carries with it a transformative role, since everything that happens in the world depends on the people who like him are preparing to transform it and generate a paradigmatic change that starts of education as such (Engelmann et al., 1995; Gustafsson, 1984; Allen et al., 1996).

Students must be creative, social entrepreneurs and good collaborators who know how to listen, respect and communicate, equipped with critical and reflective thoughts, capable of making decisions and solving problems that concern their social, cultural and family environment, they must be aware of the need to continue learning every day of their lives, that they generate leadership and that they know the difference between ethics, excellence, effectiveness, efficiency, and commitment, that they form as digital citizens and route those around them in good use of technology. As indicated Del Pozo et al. (2016), the student has an active role in their learning, always supported by their teacher at school and parents at home, should always set goals and objectives to which reach, either in the short or long term, as well as take the relevant decisions that facilitate you to reach them.

The student must be motivated to one hundred percent and if not, must be predisposed so that this stimulation is always on the rise, as well as setting objectives either short or long term, be aware of their reality, take into account the possible strategy and Overcoming options and above all be committed to the will to always get ahead. Consequently, the student must manage his motivation and look for allies that positively encourage him, to reach the goal. In the same way, the specialists mentioned above express that, the motivation must be renewable and revalidated

Delgado, J. G. L., \& Moreno, J. A. V. (2020). School motivation through the use of information and communication technologies (ICT). International Research Journal of Management, IT and Social Sciences, 7(2), 50-58. https://doi.org/10.21744/irjmis.v7n2.879 
weekly, with the help of their teacher who will guide them and help to set an itinerary, while leading them to reflect on how they are taking Carry out its learning process

According to what it indicates Peche \& Giraldo (2019), student-centered education must produce flexible, critical, reflective learning in students and have new technologies and other resources as allies innovators that promulgate a quality education and that brings new educational models that seek to make the student an innate researcher of an educational culture raised to the maximum. Authors such as Rugeles et al. (2015), suggest that another of the very important resources that the student can make use of is ICT, the same ones that are very popular with them, the innovative classes, nested with the constant motivation of the teachers, create an educational environment different from the traditional one, thus giving a facility for the student to acquire content, in a more dynamic and current way.

\section{Internal factors involved in the motivation}

Authors such as Padierna et al. (2009), argue that there are several factors involved in motivation, one of the main ones is the teacher's attention to the student since when this makes the student feel important, he feels that he must give much more, to show the teacher that his attention and motivation towards him are paid with much effort. The concentration that the student dedicates at the time the class is broadcast, is another factor that directly intervenes in the assimilation of all the contents, since the distractors are very common in a classroom, especially when the teacher does not seek the right strategy to better carry out the teaching-learning process, ensuring that these contents are assimilated correctly.

These authors also indicate that self-esteem is a fundamental part of motivation since sometimes we find very demotivated students, the same ones that the teacher will have to look for alternatives to achieve their mood. On the other hand, the perception of the environment that surrounds the student is essential since it can become a direct distractor in the classroom. The teaching process is very complex, for this reason, it implies that the current teacher must have different variables, to facilitate the issuance of the planned contents, each teacher must apply appropriate techniques, to facilitate the assimilation of the contents by part of the students, thus avoiding the various distractors who become the main barrier of the same.

Human beings have been born to learn and they do it all the time, creating their conditions for good learning and that is so significant in the different stages of their life. In such a changing and avant-garde world, learning is linked to the desire for improvement that a student may have. Being like this and at the discretion of Abascal et al. (2016), every teaching process is very complex, so it is necessary to investigate and deepen the factors that directly influence the academic performance of students who consider that these actions of teachers affect them considerably, such as:

1) Low general expectations of students.

2) Little emphasis on the review and supervision of the work done.

3) Very low teacher-student interaction.

4) The feeling that teachers don't care if they learn or not.

5) Little participation of the students in the classrooms without the necessary motivation for the change of attitude.

6) Little flexibility in tests or evaluations.

7) Lack of pedagogical feedback.

They also establish a set of variables that affect the school performance of students, these are:

1) Immediate environment.

2) Emotional stimuli.

3) Sociological needs

4) Physical needs.

5) Psychological needs

6) Reasons why

\section{External factors intervening in the motivation}

The external factors that intervene in the teaching-learning process and the degree of motivation that students should have ranged from a medical point of view, balanced feeding, the rest that comes with the relaxation; also involved sociological factors, such as entertainment and fun; communicational through which the vocabulary or positive or negative expressions used are immersed. In the same way, you should consider quiet and low-noise environments, good ventilation and lighting, the posture when studying, the distractions that may be around you, not to mention the 
time factor and the flexibility of it. In summary, all these factors considered extrinsic are linked to economic, political, cultural and environmental aspects.

\section{Types of technological tools applied for the evaluation of contents}

Evaluation is a continuous, dynamic, systematic process, through which the teacher verifies that the goals of understanding, skills and academic skills were effectively achieved by the students. In this sense the authors (Colás et al. (2005), express that the evaluation is one of the ways to measure the knowledge imparted to the students, hence the controversy over the evaluation model to be performed, the traditional evaluation where the pencil and paper are used or the new evaluations applying technologies, taking into account the variety of formats, tools and especially the ease when applying them. The creation of technological platforms focused on the evaluation process facilitates the evaluation of acquired knowledge, in addition to its graphic environment, provides various ways to add content to it, which cannot be done in the traditional evaluation, in this way the student it can be evaluated by its skill, accompanied by the theoretical knowledge taught in the classroom (Fenwick et al., 2009; Tran \& Daim, 2008).

On the other hand, these tools provide a qualification system quickly and accurately, generating a saving of time and work for the teacher, which can be used to plan or carry out other educational activities, since the platforms have the option of extract the consolidated results, and present them, if necessary, to the group of students evaluated to have greater transparency with the scores obtained. In conclusion, it constitutes a motivating tool for the attention, taste, dynamism, and modernity that surrounds it, taking into account that the student population is considered as digital natives.

\section{Positive motivation}

For education to be fully effective, it needs positive motivation both in the socio-emotional and cognitive development of each student. Naranjo (2010), considers that a constant research topic is the development of positive attitudes towards academic activities, directly related to motivation, self-esteem, positive and successful communication, as well as controlled stress management. It is important to consider the relationship between knowledge, motivation, selfesteem and communication skills and stress control, which results in the actions of the student population and their academic performance.

Ausubel as cited in (Valbuena \& González, 2018) states that school performance is a motivational factor that has a catalytic action in the cognitive process of teaching-learning, which is rather related to the affective and subjective than to the objective intellectual aspects of learning itself, considering that it is essential that students are motivated and interact inside and outside the classroom individually or in groups. An element that gives strength and drives children and adolescents to reach their goals is motivation, in this process the three fundamental pillars of education are involved: the teacher, the parent, and the student. López et al. (2017), argue that motivation is the main factor, which must be effective, volitional, where attitudes and skills must be present in academic results.

\section{Influence of ICT in school motivation}

Information technology resources are directly related to education because of its great importance, possibility, and sustainability, which give it vital advantages and benefits, hence the need to integrate them into the teaching process, as long as meaningful and lasting learning is considered in the different areas or subjects where they are implemented. The school motivation has become a challenge more than those assumed by the teacher when teaching a class, this is because sometimes he meets very daunted students, without any incentive; In these cases, the teacher must make use of different methodologies and strategies to capture the attention of the student so that he can assimilate the contents taught (Berglas, 1976).

At present, education and the teacher have new and different technological tools, which represent an important pedagogical contribution at the time of teaching, managing to deepen the content of each of the planned skills to the fullest. Information and Communication Technology, has become an excellent ally in school motivation since it facilitates the task of the teacher who energizes their classes from passive participation to the constant interaction of students. The authors Campión et al. (2014), express that educational institutions should be more soaked in the knowledge and use of new technological tools, who not only facilitate the use of content but also how to evaluate them in a way more dynamic, ensuring that education has revealing learning so that it is motivated to obtain the greatest amount of success at the time of being valued academically.

Delgado, J. G. L., \& Moreno, J. A. V. (2020). School motivation through the use of information and communication technologies (ICT). International Research Journal of Management, IT and Social Sciences, 7(2), 50-58. 
The teacher must implement constant changes in their evaluation techniques and methods, since, if these are repeated very often, the student will be demotivated, which makes it necessary to use new applications, which are widely accepted in students and easy to use creating a suitable environment for them. According to Ospina (2013), the use of educational boards, educational applications among others, have been a great contribution to the development of student creativity, an action that is reflected in the results of each of the works by students, This also implies the self-preparation of teachers, not only to explain the class but also to know about the use of current technological tools and specific applications in their daily lives. These tools provide a range of programs that can be proactively installed and used in different educational areas; Your graphic environment conversions into a dynamic, fun, motivating, participatory activity, in addition to effectively and effectively teaching the learning process.

\section{Conclusion}

The school motivation refers to the impulse felt by students to perform the tasks proposed by teachers, it must be inexhaustible; It is related to the activation of cognitive resources to absorb the knowledge imparted in educational establishments. The teacher who maintains constant motivation in their educated with the use of ICT will be able to obtain better results, since they feel more confident at the time of carrying out the different activities proposed, managing to put into practice all the knowledge imparted and acquired by the educator through a dynamic way, this is a technique that must always be applied in classrooms, thus providing greater confidence in students.

From the results of the research carried out, it is possible to recognize the influence exerted by the incorporation of ICTs in increasing school motivation, which brings with it an institutional culture with didactic curricular aspects, the academic preparation of both the teacher and the student, considering the latter as a digital native who lives and expresses himself freely with the current technological tools. Finally, the teacher must give a higher level of confidence to their students, of course, that level of trust should not be tested by both parties since at that time different types of problems can be generated that directly affect the process Learning.

\section{Conflict of interest statement}

The authors declared that they have no competing interests.

\section{Statement of authorship}

The authors have a responsibility for the conception and design of the study. The authors have approved the final article.

Acknowledgments

We are grateful to two anonymous reviewers for their valuable comments on the earlier version of this paper. 


\section{References}

Abascal, R., López, E., \& Zepeda, S. (2016). Análisis cualitativo para la detección de factores que afecta el rendimiento escolar: estudio de caso de la licenciatura en tecnologías y sistemas de información. Pistas Educativas (120).

Allen, G. L., Kirasic, K. C., Dobson, S. H., Long, R. G., \& Beck, S. (1996). Predicting environmental learning from spatial abilities: An indirect route. Intelligence, 22(3), 327-355. https://doi.org/10.1016/S0160-2896(96)90026-4

Berglas, E. (1976). Distribution of tastes and skills and the provision of local public goods. Journal of Public Economics, 6(4), 409-423. https://doi.org/10.1016/0047-2727(76)90051-7

Campión, R., Filva, D., \& Diez, A. (2014). Pueden Las Aplicaciones Educativas De Los Dispositivos Móviles Ayudar Al Desarrollo De Las Inteligencias Múltiples? Revista electrónica de Tecnología Educativa, 47.

Chai, C. S., Koh, J. H. L., Tsai, C. C., \& Tan, L. L. W. (2011). Modeling primary school pre-service teachers' Technological Pedagogical Content Knowledge (TPACK) for meaningful learning with information and communication technology (ICT). Computers \& Education, 57(1), $1184-1193$. https://doi.org/10.1016/j.compedu.2011.01.007

Colás, P., Rodríguez, M., \& Jiménez, R. (2005). Evaluación de e-learning. Indicadores de calidad desde el enfoque sociocultural. Red de Revistas Científicas de América Latina, el Caribe, España y Portugal.

Del Pozo, M., Miró, N., Hortch, M., \& Cortacans, C. (2016). Aprender Hoy y Liderar Mañana (1ª edición ed.). Tekman.

Engelmann, M., Wotjak, C. T., \& Landgraf, R. (1995). Social discrimination procedure: an alternative method to investigate juvenile recognition abilities in rats. Physiology \& behavior, 58(2), 315-321. https://doi.org/10.1016/0031-9384(95)00053-L

Estevez, A. G., Roche, J. R. F., Espinosa, A. H. R., \& Rodríguez, D. L. (2018). Social skills training program to prevent alcohol consumption in university students. International Journal of Health Sciences, 2(3), 43-54. https://doi.org/10.29332/ijhs.v2n3.216

Fenwick, D., Daim, T. U., \& Gerdsri, N. (2009). Value Driven Technology Road Mapping (VTRM) process integrating decision making and marketing tools: Case of Internet security technologies. Technological Forecasting and Social Change, 76(8), 1055-1077. https://doi.org/10.1016/j.techfore.2009.04.005

García, F., \& Doménech, F. (2014). Motivación, Aprendizaje Y Rendimiento Escolar. Revista Electrónica de Motivación y Emoción.

Gustafsson, J. E. (1984). A unifying model for the structure of intellectual abilities. Intelligence, 8(3), $179-203$. https://doi.org/10.1016/0160-2896(84)90008-4

Herianto, E. (2017). The effect of learning strategy, achievement motivation, and communication skill toward learning outcomes on the course PMPIPS-SD at PGSD. International Research Journal of Management, IT and Social Sciences, 4(5), 1-11.

Horch, M. (2016). La Escuela del Siglo XXI: Transformaciones para la Innovación Educativa. Barcelona: NazaretGlobalEducation.

Huang, Y. M., \& Chiu, P. S. (2015). The effectiveness of the meaningful learning-based evaluation for different achieving students in a ubiquitous learning context. Computers \& Education, 87, $243-253$. https://doi.org/10.1016/j.compedu.2015.06.009

Huang, Y. M., Chiu, P. S., Liu, T. C., \& Chen, T. S. (2011). The design and implementation of a meaningful learningbased evaluation method for ubiquitous learning. Computers \& Education, 57(4), $2291-2302$. https://doi.org/10.1016/j.compedu.2011.05.023

Lasala, T., Mcvittie, J., \& Smitha. (2013). Disciplina Positiva en la Escuela y Salón de clase, Guía del Maestro: Actividades para estudiantes. 2. Estados Unidos: Positive Discipline Association.

López, I., Cruz, M., \& Cruz, N. (2017). La motivación de los estudiantes de enfermería. UTMACH, 1(1), 1.

Naranjo, M. (2010). Factores que favorecen el desarrollo de una actitud positiva hacia las actividades académicas. Educación, 34(1), 32.

Ospina, C. (2013). Las tics como herramienta de motivación en el aula. Universidad de la sabana.

Ospina, J. (2015). La motivación, motor del aprendizaje. Ciencia y Salud.,

Padierna, J., Oseguera, J., \& Gudiño, N. (2009). Factores socioacadémicos, estilo de aprendizaje, nivel intelectual y su relación con el rendimiento académico previo de médicos internos de pregrado. Vigueras editores.

Peche, H., \& Giraldo, V. (2019). El Aprendizaje Flip Learning centrado en el estudiante como generador de calidad educativa. Dialnet, 4(8).

Pérez, J., \& Gardey, A. (2012). Definición de cognitivo-Qué es, Significado y Concepto.

Delgado, J. G. L., \& Moreno, J. A. V. (2020). School motivation through the use of information and communication technologies (ICT). International Research Journal of Management, IT and Social Sciences, 7(2), 50-58. 
Precht, A., Valenzuela, J., Muñoz, C., \& Sepúlveda, K. (2016). Familia y motivación escolar: desafíos para la formación inicial docente. Estudios pedagógicos (Valdivia), 42(4), 165-182. http://dx.doi.org/10.4067/S071807052016000500010

Rick, S., \& Weber, R. A. (2010). Meaningful learning and transfer of learning in games played repeatedly without feedback. Games and Economic Behavior, 68(2), 716-730. https://doi.org/10.1016/j.geb.2009.10.004

Rugeles, P., Mora, B., \& Matute, P. (2015). El rol del estudiante en los ambientes educativos mediados por las TIC. Lasallista de Investigación, 132-138.

Sandoval-Muñoz, MJ, Mayorga-Muñoz, CJ, Elgueta-Sepúlveda, HE, Soto-Higuera, AI, Viveros-Lopomo, J., \& Riquelme Sandoval, SV (2018). School commitment and motivation: A conceptual discussion. Education Magazine , 42 (2), 66-79. http://dx.doi.org/10.15517/revedu.v42i2.23471

Tran, T. A., \& Daim, T. (2008). A taxonomic review of methods and tools applied in technology assessment. Technological Forecasting and Social Change, 75(9), 1396-1405. https://doi.org/10.1016/j.techfore.2008.04.004

Usán Supervía, P., \& Salavera Bordás, C. (2018). School Motivation, Emotional Intelligence and Academic Performance in Students of Secondary Education. News in Psychology, 32 (125), 95-112. http://dx.doi.org/10.15517/ap.v32i125.32123

Valbuena, J., \& González, M. (2018). La Motivación es el Motor para Aprender en el Aula. Uniminuto edu.

Vega, O. (2016). De las TIC en la educación a las TIC para la educación. Vector, 11, 1. 